Journal of Urban and Regional Analysis, vol. XII, 1, 2020, p. $401-415$

https://doi.org/10.37043/JURA.2021.13.2.11

\title{
IDENTIFYING PATTERNS OF LABOUR EXCLUSION BY RESIDENTIAL CAUSES IN SOUTH AMERICA: THE CASE OF QUITO
}

\author{
Susana HERRERO OLARTE \\ Universidad de Las Américas, Quito, Ecuador
}

\begin{abstract}
The lack of opportunities for employment is still present in most South American cities. This arises as a problem due to its impact on chronic poverty and social mobility, two of the main challenges in the region. Therefore, the aim of this paper is to identify the causal link between residential location and labour market exclusion, and its effects on development, geography, and urbanism. This paper uses an urban mobility approach to define the geographic poverty pattern and to generate new tools for the development of local policies in Quito. It also delves the lack of opportunities to access employment, as representing the main source of urban poverty growth in South America, especially due to residential location. The analysis applies the Multidimensional Poverty Index (MPI) and the Labour Exclusion by Residential Causes Index (LERCI) to each Quito parish. LERCI includes variables of distance, cost, and public transportation density. Our results regarding the correlation between the two indices suggest a pattern of labour exclusion by residential causes that includes two different dimensions of urban poverty - one in downtown parishes and the other in the periphery.
\end{abstract}

Key Words: urban poverty, labour exclusion, urban mobility, Quito.

\section{Introduction}

The term of exclusion, used to refer to a lack of opportunities, focuses on the causes rather than the symptoms of poverty and it can reduce chronic poverty and the limits of social mobility (Lenoir 1974, Commission of the European Communities 1992, Room 1992, Silver 1994, Gore and Figueiredo 1997), two of the main challenges in South American cities (Gacitúa et al. 2000, UNHabitat 2003). This paper delves into the lack of opportunities to access employment, the main source of urban poverty reduction in the region (Bauer 1957, Carrión 1990, Unda 1990, Paes De Barros et al. 2008). It explores the idea that residential location is a cause of exclusion from the labour market, which implicitly includes other reasons, such as gender or ethnicity (Bastia 2015), and it has externalities in different areas, such as development studies (Seers 1969, Maxwell 1998), human geography and urbanism. The study of the challenges of the relationship between urban mobility for arriving in the labour market and poverty can offer a pattern to define new tools for the development of local policies.

Focusing on recent demography and poverty data, and especially on its projections, many South American cities with more than one million people (excluding largest urban agglomerations), have become priorities. They have the worst poverty data, and they are expected to undergo a major increase of population in the future (Borsdorf et al. 2002, United Nations 2014). Under such considerations, we explore patterns of labour exclusion by residential causes in the city of Quito.

\section{Theoretical Framework}

The exclusion condition is understood as relative deprivation (Townsend 1979, De Haan 1998) or as lack of opportunities to participate (Bourguignon and Chakravarty 2019) in basic economic, 
political and social activities in the area of reference (Figueroa 2001) — or, in Sen's (1997) words, a deprivation of the ability to overcome poverty.

As relative deprivations are different depending on the time and the chosen area, strategies to reduce them must consider similar experiences but they also must be individually designed. In addition, as deprivations are multi-faceted and changeable (De Haan 1998), the design of public policies to reduce the lack of opportunities must also quantify its positive and negative externalities into other related dimensions of exclusion.

To operate a public policy to reduce exclusion and poverty (Kaztman 2003), it is necessary to define the "attribute" and the "space" (Zohir 2006). The "attribute" is the reason of relative deprivation or the lack of opportunity, while the "space" is the relative deprivation or the lack of opportunity (Zohir 2006). The "attribute" must be objective and measurable, such as the place of residence, gender, and ethnicity (Zohir 2006). "Space" must consider the weight of each possible relative deprivation in each area (Zohir 2006). For example, regarding economic participation, it can consider employment, self-employment, and the public support but it is necessary to define which issue in each area and moment is relevant. In addition, the lack of opportunities must increase poverty. Examples of "spaces" could be the difficulty of finding a job or the limit of access to a corporate credit.

Attaining facts is the first step to define public policies with the objective of reducing exclusion and, consequently, poverty. In South America, urban poverty is a case of residential segregation (Massey et al. 1996, Wilson 2012). It is characterized by the trend of social groups concentrating in homogeneous neighbourhoods with the subjective perception of objective segregation (Rodríguez Vignoli 2001, Sabatini et al. 2009). This segregation is a consequence of the historical arrangement of cities defined by the regional dominant class and the public budget dedicated to investing in urbanism. The main South American cities were created to accumulate people with a military objective (Slack et al. 2016), following the Spanish and Portugal model around a central plaza, which we now identify as the downtown. Professionals and employees arrived from the villages to the nearby neighbourhoods (Portes 1976). Those who obtained titles to possess land had not just economic sources but also belonged to the dominant class. As the budgets of the towns were minimal, the areas that received the greatest part of the public budget were the neighbourhoods where the dominant classes lived. In the $19^{\text {th }}$ century, the pressure over the downtown increased because of the demographic growth of the dominant class and the proximity of the poor neighbourhoods. As a result, the dominant class moved, creating other neighbourhoods. Such was the case of La Mariscal in Quito (Bustamente-Patiño and HerreroOlarte 2017) or of "Barrio Republica" in Santiago de Chile (Rodríguez Vignoli 2008). The scheme repeated in every generation, and new dominant class neighbourhoods were created, giving shape to the current cities. At the same time, people in poor conditions created new neighbourhoods not just because of the natural rise of demography but due to new migration from the rural areas (Muwonge 1980, Costello 1987). As the number of poor neighbourhoods increases, their density rises, and the stagnation of living conditions call the attention of development studies, human geography, and urbanism.

Development studies on urban poverty deepened into the causes of marginality and they seek the ability to reduce it. Based on the "marginality theory" (Park 1928, Smith 1934, Goldberg 1941, Green 1947), the lack of access to development (Giusti 1973) and their non-participation in the decision structures of the society (Vekemans and Silva 1969) were by-products of the inability of cities to modernize and to integrate the rural migrants (United Nations 1963). According to the "dependent urbanization theory", the heir of the works related to the "dependency theory" of South America; in developed countries (Cardoso and Faletto 1971), the problem was the capitalism that 
permitted marginality to press salaries downward and to have workforces available (Murmis 1969). Focusing on the search of possible solutions independently of the causes (Singer 1977) and taking into consideration the public capability to avoid marginality, Perlman (1977) voiced the ability of the outsiders to improve their quality of life and to overcome poverty. At the end of the "lost decade", there was reinforced the idea of the capabilities of the outsiders and of their heterogeneity, even within the groups, to improve their quality of life and to overcome poverty in each specific area and to negotiate public policies (Herrero-Olarte and Díaz-Márquez 2020).

In the nineties, the concept of marginalization in South America was related to urban poverty, which was influenced by the ideas of Sen (Sen and Williams 1982, Drèze et al. 1995, Sen 1997), and it was very similar to the exclusion idea developed at the end of the 20th century in order to refer to urban poverty in Europe (Deleeck and Van Den Bosch 1992, Secretary of State for Social Security 1999). The proposals on marginalization agreed that the poor people were not outsiders; they were in marginal conditions because of their relationship with the economic, political, and social structures. Generally, they could not have access to these structures, or they were used because of the system (Castells 2020). When poor people could not change the system, they were "vulnerable", but if they could change the system, they had the needed "assets" or the economic, social, or natural resources to improve their quality of life (Kabir et al. 2012).

Despite that there are a lot of dimensions that influence poverty, especially considering its multidimensionality, the low income is especially relevant. In the case of the World Bank and the European Union, the variable income is still used to measure poverty and it is included in the calculation in the majority of multidimensional poverty indices, such as UBN, HPI-2 or MPI.

In South American cities, the access to employment is the primary source of income; as such, it is the fundamental variable for analysing poverty reduction. In the future, it will be increasingly significant because of the growing trend of market forces and the reduction of the role of the state (De Mattos 2002), as well as the growing trend of low-skilled workers in urban areas (Sepúlveda Morales 2019).

Studies of economic and urban geography in South America developed the concept of residential location as an attribute of exclusion through qualitative works to describe the living conditions in the socioeconomic segregated neighbourhoods, as well as the relationship between them and the rest of the city (Prévôt Schapira 2000 - in Buenos Aires, Sabatini and Arenas 2000 - in Santiago de Chile, Pérez Valbuena and Salazar Mejía 2008 - in Cartagena, or Tachner and Bógus 2001 in Sao Paulo).

To deepen the relationship between residential location and the lack of access to employment in South America, it is necessary to attend transport studies of urbanism and economy related to the concept of mobility, understood as the group of individual forms of displacements, their reasons, results, context, and conditions (Miralles i Guasch et al. 2000, Miralles-Guasch 2002, Figueroa 2005, Sanz 2005). Most of them perform qualitative work reinforcing the link between the access to opportunities to reduce poverty and the increase of mobility in general (ITRANS 2004, Castañeda Nordmann and Gómez López 2020). Some of them go deeper into the relationship between poor mobility and the access to employment (Sabatini et al. 2009, Venter 2016).

People who live in places where the economy is not thriving tend to respond to insecure labour markets by moving to residential areas where there are more opportunities for them and their families (Preece 2018). Nonetheless, some argue that mobility is less common for the unemployed, as economically inactive agents who live far from residential areas (Bailey and Livingston 2008). Parts of the population who perceive low-income levels and are economically 
vulnerable may live in rural areas, not close to the economic parts of the city. Hence, they may be forced to encounter low-quality transport, longer journeys, higher costs, and exposure to pollution and accidents (Titheridge et al. 2014).

The link between the lack of mobility and economic and social exclusion derives from the supply of transport. In fact, transport provides access to labour market participation, education, and social activities for the marginalized parts of the society (Lucas 2012). For example, due to the concentration of educational and labour opportunities in specific parts of Bogotá, Colombia, inequality has risen because of the poor access to these activities that affected primarily the agents with low-income levels (Bocarejo and Oviedo 2012). In addition, Guzmán et al. (2017) find that, in Colombia, transport policies for urban mobility have helped to cope with the inequalities caused by the poor transport and socio-spatial infrastructure, where economic and education opportunities are concentrated in specific parts of the capital.

There is still a discussion on whether the parts of the population who live in disadvantaged urban and rural areas are immobile. In fact, they are often seen as trapped because of a lack of aspiration and access to mobility into economically competitive urban areas (Preece 2018). As unemployment remains a long-term factor for the marginalized and working-class agents, they may feel insecurity in moving in the search of new opportunities (Bourdieu 1990, Atkinson 2008). Therefore, the agglomeration of economic activities in certain parts of cities, the uncertainty and insecurity of labour markets and the difficult access to transportation deter the probability of mobility for low-income individuals to places of opportunity and growth (MacKinnon and Driscoll Derickson 2013, Martin et al. 2016).

The objective of this study is to find if residential location and economic agglomeration are determinants of exclusion from the labour market. Its aim is to define new tools for the development of local policies in Quito, a city with a high concentration of the population, where poverty and inequality are present and rising. We focus on finding the link between urban mobility towards the areas with more labour market opportunities and poverty, to propose policies that foster economic opportunities, equality, and development for the least favoured parts of the population. This paper deepens the relationship between mobility, employment, and poverty, known as residential labour exclusion in urban South America, modelled on a medium-sized city such as Quito.

Despite the significant poverty and inequality reductions achieved in Latin America, some types of exclusion and inequality remain to this day, one of them being related to mobility and its barrier to equitable progress (Deneulin and Sánchez-Ancochea 2018). Mobility policies and regulations have been at the centre of many cities in Latin America, with the objective of increasing the inclusion of low-income individuals and to reduce inequality (Oviedo et al. 2019). However, these methods for urban mobility follow the traditional guidelines that focus on efficiency rather than on spatial and social equality (Keeling 2008). Most economic epicentres in Ecuador and the Latin American region keep centralized distributions of educational and economic opportunities. Therefore, housing and land prices increase in these areas with strong economic activity, pushing poor people towards the urban peripheries, where the living costs are more affordable (Drewnowski and Scott 1966), and accentuating the exclusion of people who live far away (Guzman et al. 2017a, Guzman et al. 2017b).

As the region contains most of its population in urban areas, more complex transport and travel structures have arisen. However, these are served by formal and informal systems with low-quality standards and services (Hidalgo and Huizenga 2013). Hence, inequalities become an issue regarding the location of the citizens, affecting their mobility and access to the urban economic and employment opportunities (Jouffe 2011). Ecuador is not an exception when it comes to 
economic exclusion within urban regions and between urban and rural areas. In fact, poverty levels reach $20 \%$ in urban areas, but this percentage increases to $33 \%$ in rural areas and it accentuates for the indigenous people, with 64.8\% in 2014 (Palacio Ludeña and Díaz Pabón 2020). In the capital of Ecuador, Quito, approximately $70 \%$ of people use public transport as their main mean of transportation (Zárate 2018). In Quito, peripheral areas suffer from the low quality and supply of public means of transportation. So, as in many other cities in the country and the region, the individuals who live in the marginalized sectors need public transport to seek and to access economic, educational, and social opportunities (Guzman Jaramillo et al. 2019). This is of great importance, given the fact that some studies have found that roughly $88 \%$ of poverty in Quito is attributed to distance, density of public transportation, education, ethnicity, and healthcare (Herrero Olarte 2019).

\section{Methodology}

To define the pattern of the relationship among urban mobility, employment, and exclusion, we relate two indices calculated using data from 32 urban parishes in Quito. The first is a product of exclusion, which is the Multidimensional Poverty Rate (MPR); the other is the Labour Exclusion by Residential Causes Index (LERCl), which studies the variables of distance, cost and public transportation density in each parish using Iñaquito as reference, the financial centre and the parish that generates the most jobs in Quito (22.5\%).

The methodology of the National Institute of Statistics and Censuses (NISC) of Ecuador, based on the work of Alkire and Foster (2011), was used to calculate the Multidimensional Poverty Rate (MPR) by parish (Table 1). NISC uses twelve indicators obtained from the National Survey of Employment, Unemployment and Underemployment (NSEUU). From this survey, it is not possible to calculate data at a parish level because it becomes non-representative ${ }^{1}$. Consequently, in the present study, data from the National Census of Population and Housing 2010 were used; these data are representative at a parish level ${ }^{2}$. From the census database, it is possible to calculate ten of the twelve indicators that NSEUU considers, omitting those that include income.

The MPR is calculated as the percentage of citizens that keep three of the ten poverty indicators. When a person has five or more poverty indicators, (s)he is considered extremely poor.

To determine if social exclusion produces more poverty, it is necessary to match each poverty area with a limit of opportunities and to construct an indicator with those limits. In this case, each dimension or group of dimensions of the MPR corresponds to a limit to overcome it. Labour Exclusion by Residential Causes Index (LERCI) includes the limit of access to employment.

For the current model, the independent mobility variables were aligned with the social inclusion and exclusion model of Shove (2002). When considering physical access to work, it can be said that the lack of accessibility will depend on: (a) the distance, measured as the average in kilometres that a person travels until arriving to work; (b) public transport, understood as the public transportation infrastructure available in each parish; and (c) the cost, understood as the monetary value to move from one parish to another.

${ }^{1}$ Loss of representativeness prevented the use of $\mathrm{NBI}$, which is by parish but based on both the Census and the NSEUU.

${ }^{2}$ The bases of the census of housing, home, emigration, and population have been unified to avoid the duplication of records and to consider only housing data with their corresponding homes and population. 
Variables for calculating the Multidimensional Poverty Index (MPI) by parishes in Quito and by cantons at national level

\begin{tabular}{|c|c|c|c|c|c|}
\hline \multicolumn{2}{|c|}{ Dimension } & \multirow{2}{*}{$\begin{array}{l}\text { Deficiencies } \\
\text { Non-attendance } \\
\text { at basic and } \\
\text { high school } \\
\text { education }\end{array}$} & \multirow{2}{*}{$\begin{array}{l}\text { Definition of Deficiency } \\
\text { Children between } 5 \text { and } 14 \text { years old who do not attend a } \\
\text { basic education centre and young people between the ages } \\
\text { of } 15 \text { and } 17 \text { who do not attend high school. }\end{array}$} & \multirow{2}{*}{$\begin{array}{c}\begin{array}{c}\text { INEC } \\
\text { Weighting } \\
\text { (National) }\end{array} \\
33 \%\end{array}$} & \multirow{2}{*}{$\begin{array}{c}\text { CENSUS } \\
\text { Weighting } \\
\text { (Parishes) }\end{array}$} \\
\hline \multirow{3}{*}{ 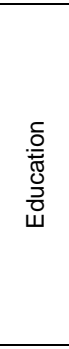 } & \multirow{3}{*}{ ㅇํํ } & & & & \\
\hline & & $\begin{array}{l}\text { No access to } \\
\text { higher education } \\
\text { for economic } \\
\text { reasons }\end{array}$ & $\begin{array}{l}\text { Young people between the ages of } 18 \text { and } 29 \text { who, having } \\
\text { completed high school, cannot access a third-level higher } \\
\text { education centre due to the lack of financial resources. }\end{array}$ & $33 \%$ & - \\
\hline & & $\begin{array}{l}\text { Incomplete } \\
\text { educational } \\
\text { achievement }\end{array}$ & $\begin{array}{l}\text { Persons between the ages of } 18 \text { and } 64 \text { who have not } \\
\text { completed basic education, i.e., who have less than } 10 \text { years } \\
\text { of schooling and who do not attend a formal school. }\end{array}$ & $33 \%$ & $50 \%$ \\
\hline \multirow{3}{*}{ 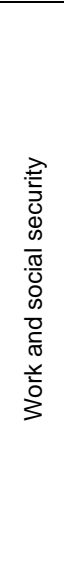 } & \multirow{3}{*}{ ㅇํํ } & $\begin{array}{l}\text { Child and } \\
\text { adolescent } \\
\text { employment }\end{array}$ & $\begin{array}{l}\text { Boys and girls between the ages of } 5 \text { and } 14 \text { who are } \\
\text { employed during the school week are identified as deprived, } \\
\text { since child labour is prohibited. Adolescents between } 15 \text { and } \\
17 \text { years of age are considered deprived of the right to work } \\
\text { if, although employed, during the school week they fulfil one } \\
\text { of the following conditions: they received a remuneration } \\
\text { lower than the Unified Basic Salary, they did not attend } \\
\text { classes, or they worked more than } 30 \text { hours. }\end{array}$ & $33 \%$ & $33 \%$ \\
\hline & & $\begin{array}{l}\text { Unemployment } \\
\text { or inadequate } \\
\text { employment }\end{array}$ & $\begin{array}{l}\text { People } 18 \text { years of age or older who, in the reference period, } \\
\text { were unemployed. In addition, employed persons with } \\
\text { inadequate employment (underemployment) are considered } \\
\text { deprived. }\end{array}$ & $33 \%$ & $33 \%$ \\
\hline & & $\begin{array}{l}\text { Non-contribution } \\
\text { to the pension } \\
\text { system }\end{array}$ & $\begin{array}{l}\text { Employed people aged } 15 \text { years or over who do not } \\
\text { contribute to any kind of social security, excluding the } \\
\text { persons aged } 65 \text { and over who do not contribute but receive } \\
\text { retirement pensions. People aged } 65 \text { or over who are } \\
\text { unemployed or economically inactive are considered } \\
\text { deprived if they do not receive a retirement pension, the } \\
\text { Human Development Stipend or the Joaquín Gallegos Lara } \\
\text { Stipend. }\end{array}$ & $33 \%$ & $33 \%$ \\
\hline \multirow{2}{*}{ 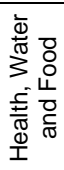 } & \multirow[b]{2}{*}{ ㅇํㅇ } & $\begin{array}{c}\text { No public water } \\
\text { service }\end{array}$ & $\begin{array}{l}\text { Households that obtain water through a medium other than } \\
\text { the public grid. }\end{array}$ & $50 \%$ & $100 \%$ \\
\hline & & $\begin{array}{l}\text { Extreme poverty } \\
\text { based on } \\
\text { income }\end{array}$ & $\begin{array}{l}\text { People whose per capita household income is lower than the } \\
\text { extreme poverty line. }\end{array}$ & $50 \%$ & - \\
\hline \multirow{4}{*}{ 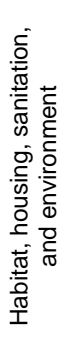 } & \multirow{4}{*}{ ㅇํํ } & Overcrowding & Households who have more than three people per bedroom. & $25 \%$ & $25 \%$ \\
\hline & & Housing deficit & $\begin{array}{l}\text { People whose housing, due to the materials or condition of } \\
\text { their walls, floors, and ceilings, are deemed to have a } \\
\text { qualitative or quantitative deficit. }\end{array}$ & $25 \%$ & $25 \%$ \\
\hline & & $\begin{array}{l}\text { No sewage } \\
\text { service }\end{array}$ & $\begin{array}{l}\text { People in urban areas whose homes do not have toilet } \\
\text { service connected to a sewer. In rural areas, deprived } \\
\text { people are those whose dwellings do not have a sewer or a } \\
\text { septic tank. }\end{array}$ & $25 \%$ & $25 \%$ \\
\hline & & $\begin{array}{l}\text { No trash } \\
\text { collection } \\
\text { service }\end{array}$ & $\begin{array}{l}\text { People living in homes that do not have access to the } \\
\text { municipal waste collection service are classified as deprived } \\
\text { in this indicator. }\end{array}$ & $25 \%$ & $25 \%$ \\
\hline
\end{tabular}

Source: the author's elaboration using data from the National Institute of Statistics and Censuses (NISC) of Ecuador 
The independent variable distance (a) estimates the average in kilometres that the citizens travel to arrive from the centre of their parish of residence to the centre of the parish of Iñaquito ${ }^{3}$. To measure (a), it is necessary to calculate (a.1), which is the distance by public transport from the centre of each parish to the centre of the parish of Iñaquito ${ }^{4}$. For this, the average distance in kilometres of several possible routes is taken. The information to calculate (a.1) was provided by the Ministry of Mobility for the Municipality of Quito.

The independent variable public transportation density (b) by parish is calculated by multiplying the number of public transportation lines (b.1) per parish by the frequency of lines (b.2) and by dividing this result by the total population of the parish. The number of available lines is defined as all those in operation ${ }^{5}$ while the frequency takes the number of available units per hour in each parish (articulated and bi-articulated buses used for the Ecovía and the Central Corridor Trolleybus are excluded). Frequency takes the number of units for the different modes of transportation. The last independent variable is the cost (c), which is calculated according to the best possible routes by the public transportation that citizens can take to get to the centre of the parish of Iñaquito.

The formula to calculate the Labour Exclusion by Residential Causes Index (LERCI) is presented by this equation:

$$
\operatorname{LERCI} I_{p}=[\operatorname{Ln} a-\operatorname{Ln} b+\operatorname{Ln} c]_{p}
$$

(a) Average distance in kilometres, (b) public transportation density, (c) cost of public transportation, and $(p)$ each parish.

\section{Results}

The Multidimensional Poverty Rate (MPR) in Quito was $16 \%$, which means that 268,906 people have three of the eight poverty indicators of the National Institute of Statistics and Censuses (NISC) obtained by the census database. The parishes with the highest MPR were Guamaní to the south of Quito, La Libertad in downtown and El Condado in the north, with values of $32 \%$, $30 \%$ and $29 \%$, respectively. The parishes with the lowest MPR were Iñaquito with $2 \%$, La Concepcion with $3 \%$, and Mariscal Sucre with $4 \%$ (Table 2).

LERCI ranges from less than 0 to approximately 5.5 among the parishes; those that are closer to 0 are those that show a better indicator, while those that are close to 5.5 present problems of distance, which results in time expenditure, lack of infrastructure for public transportation and a higher cost of transportation. Turubamba (5.4), El Condado (4.8), La Mena (4.6), Chillogallo (4.3) and Gumaní (4.2) are the five parishes with the biggest indicator within Quito; consequently, they show the most problems in terms of distance, public transportation, and cost. On the other hand, Mariscal Sucre (-0.01), Centro Historico (0.01), Jipijapa (0.36), Rumipamba (0.46) and Itchimbia $(0.65)$ are the parishes with the lowest LERCI, indicating good features in transportation and location.

${ }^{3}$ The parish of Iñaquito generates the largest number of jobs in Quito, with $22.5 \%$ of the total. This figure was identified based on the analysis of a sample of 347 companies out of the nearly 3,600 active people in Quito in 2010. This information was provided by the Municipality of Quito.

${ }^{4}$ The modes of transportation considered are all those used in Quito: Ecovía, Central Corridor Trolleybus, North Central Corridor, Southeastern Corridor, Southwestern Trunk, Integrated System Routes, Extensions, Interparish, and Intra-parish Routes and Conventional and Individual Routes.

${ }^{5}$ Idem. 
Multidimensional Poverty Rate (MPR) and Spatial Exclusion Index (SEI) in Quito

\begin{tabular}{|r|l|r|r|r|l|l|l|}
\hline & Parish & MPR & SEI & & Parish & MPR & SEI \\
\hline 1 & Belisario Quevedo & $15 \%$ & 1.69 & 17 & LA ARGELIA & $23 \%$ & 3.70 \\
\hline 2 & Carcelén & $12 \%$ & 2.40 & 18 & LA ECUATORIANA & $24 \%$ & 2.91 \\
\hline 3 & Centro Histórico $\left(^{*}\right)$ & $22 \%$ & 0.01 & 19 & LA FERROVIARIA & $21 \%$ & 2.75 \\
\hline 4 & CHILIBULO & $18 \%$ & 3.46 & 20 & LA LIBERTAD $\left.{ }^{*}\right)$ & $30 \%$ & 3.84 \\
\hline 5 & CHILLOGALLO & $24 \%$ & 4.27 & 21 & LA MAGDALENA & $7 \%$ & 1.63 \\
\hline 6 & CHIMBACALLE & $10 \%$ & 1.61 & 22 & LA MENA & $16 \%$ & 4.58 \\
\hline 7 & COCHAPAMBA & $22 \%$ & 4.12 & 23 & MARISCAL SUCRE & $4 \%$ & -0.01 \\
\hline 8 & COMITÉ DEL PUEBLO & $19 \%$ & 2.31 & 24 & PONCEANO & $10 \%$ & 1.81 \\
\hline 9 & LA CONCEPCIÓN & $3 \%$ & 0.90 & 25 & PUENGASÍ & $16 \%$ & 2.95 \\
\hline 10 & COTOCOLLAO & $7 \%$ & 2.29 & 26 & QUITUMBE & $19 \%$ & 4.06 \\
\hline 11 & EL CONDADO & $29 \%$ & 4.83 & 27 & RUMIPAMBA & $5 \%$ & 0.46 \\
\hline 12 & GUAMANÍ & $32 \%$ & 4.19 & 28 & SAN BARTOLO & $10 \%$ & 1.02 \\
\hline 13 & ITCHIMBÍA & $10 \%$ & 0.65 & 29 & SAN ISIDRO DEL INCA & $17 \%$ & 3.44 \\
\hline 14 & INANAUITO & $2 \%$ & - & 30 & SAN JUAN $\left.{ }^{*}\right)$ & $18 \%$ & 1.04 \\
\hline 15 & JIPIJAPA & $7 \%$ & 0.36 & 31 & SOLANDA & $11 \%$ & 2.46 \\
\hline 16 & KENNEDY & $7 \%$ & 1.70 & 32 & TURUBAMBA & $28 \%$ & 5.40 \\
\hline
\end{tabular}

Source: the author's elaboration from the model estimates

There is a positive relationship between MPR and LERCI, which means that there is a direct relationship between multidimensional poverty and the distance in kilometres to the parish with more jobs, as well as the cost of arriving and the public transportation available (Fig. 1, Fig. 2). Indeed, the parishes with the higher MPR were the same in general with the higher LERCl, which is the farthest from the parish of Iñaquito. The value of the correlation coefficient between MPI and LERCI is 0.75 , and the $\mathrm{R}$ coefficient is 0.56 , which shows a relationship between residential location and poverty. Despite the strong correlation between the two indicators, there is a group of parishes with a small correlation between MPR and LERCl, including the parish in the natural centre of the city. Excluding downtown parishes (the Historical Centre, San Juan, and La Libertad), the value of the correlation coefficient is 0.86 , and the $R$ coefficient is 0.75 . The results suggest a pattern of labour exclusion by residential causes that includes two dimensions of urban poverty: in downtown parishes and in the periphery. 


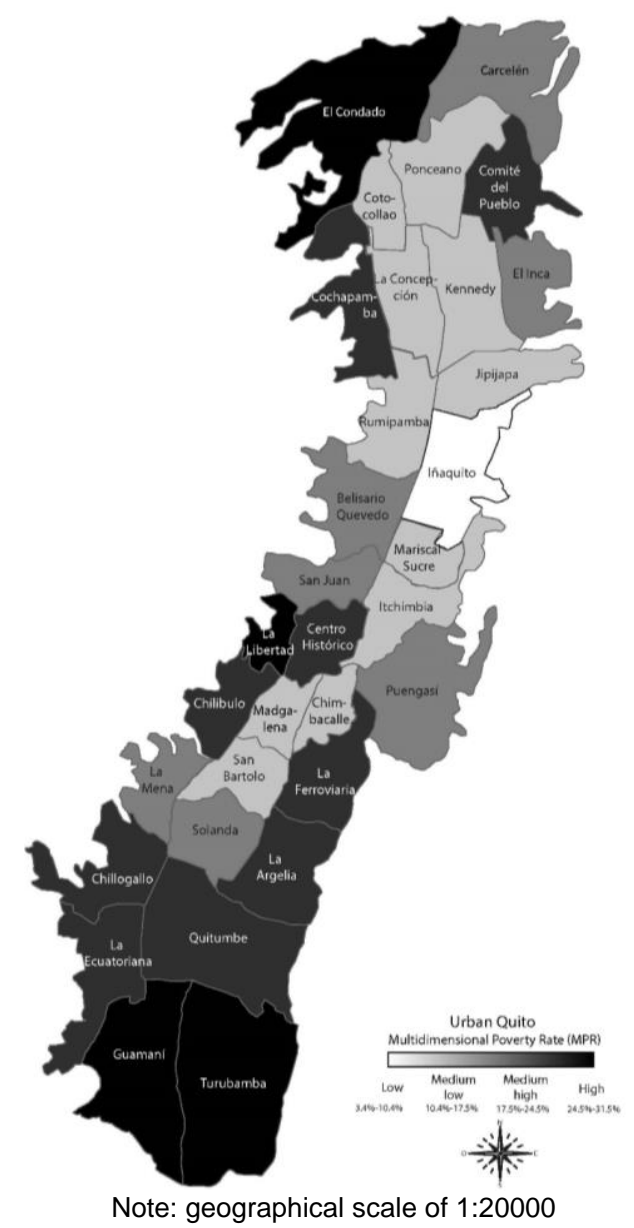

Fig. 1 - Multidimensional Poverty Rate (MPR) in urban parishes

Source: compiled by the author using the

Population and Housing Census of 2010 and the database provided by the Municipality of Quito

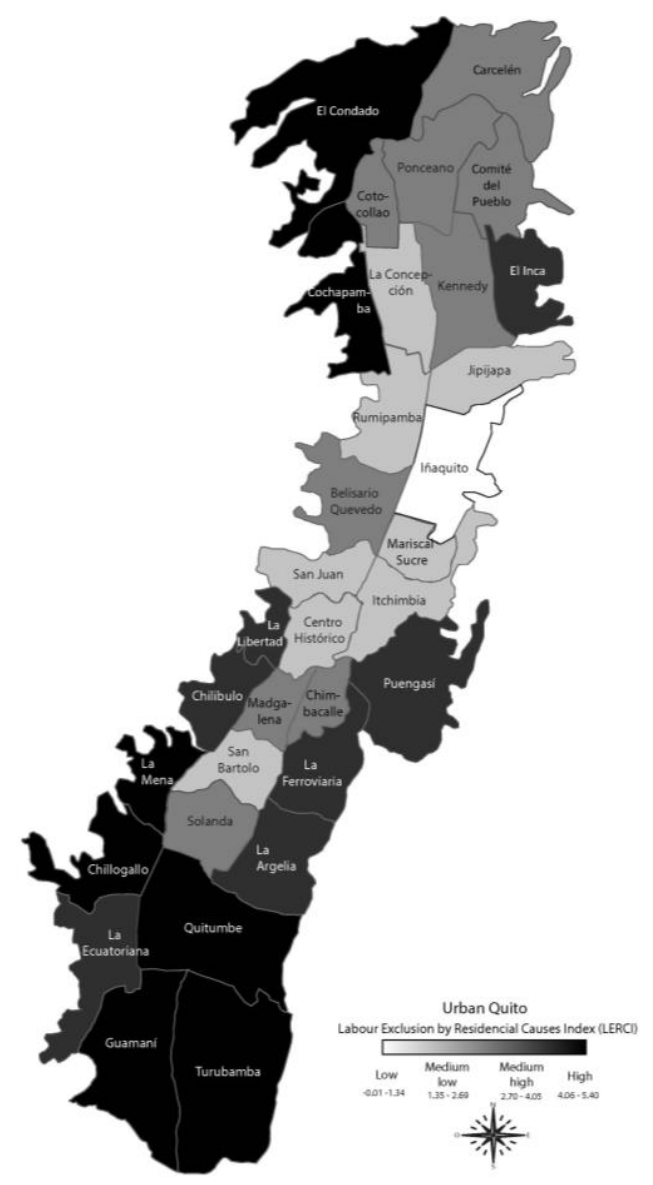

Note: geographical scale of 1:20000

Fig. 2 - Labour Exclusion by Residential Causes Index (LERCI) in Quito urban parishes Source: compiled by the author using the Population and Housing Census of 2010 and the database provided by the Municipality of Quito

\section{Discussion}

The correlation between the MPI and the LERCI in each parish is stronger without considering that the three parishes in the centre of the city suggest that there is a pattern of labour exclusion by residential causes in Quito. The pattern relates labour exclusion and urban mobility in two ways. On one hand, there is a link between the parishes with low mobility, given the distance, the cost, and the available public transportation, as well as with multidimensional poverty. There are also parishes on the periphery of the city. On the other hand, some parishes in the centre have high levels of poverty and good mobility. Comparing poverty on the periphery and in the city 
centre, the origin was obvious; in the centre, poverty is a legacy of the impoverished employees of the first dominant classes, but in the periphery, they are migrants who arrived later to the city.

Public policies to reduce poverty in Quito should devise a strategy to breakdown the social barriers to overcoming poverty in the city centre. Two scenarios appear in this context. On one hand, there is a possibility of improving public and private transport to approach the parishes on the periphery to the parish of Iñaquito. There are different options in this course of action. The invest would increase and create the number of public transports available on the existing routes and it would create new other routes. It could improve the people capability to have a work, and consequently to reduce poverty. Nowadays, there are some many objections to this strategy. In the case that the roads don't increase, the most probable scenario, the traffic would increase, generating two undesirable consequences. There would be more contamination and the time to arrive to the work would increase. These are two of the main challenges of South American cities (Zalakeviciute et al. 2018, Díaz-Márquez 2019). Consequently, the approaching of the parishes on the periphery through increasing public transport can be doubted as the selected public policy to improve the possibilities of working. On the other hand, the idea of multiple centralities has become especially relevant in this context. Multiple centralities generate small economies of scale that produce different nucleus to increase the jobs supply. This proposal can reduce contamination, and the time to arrive to work, setting it up as the best in this context.

\section{Conclusions}

Although this research limits its operational analysis to Quito, cities with a similar past and population, one to five million people, will increase from 45 million in 2015 to 52 million in 2030. These large cities, but not the megalopolises, will grow larger, and most of their people will live in urban poverty. This search for patterns of labour exclusion by residential causes can be developed in other cities too to offer more tools from development studies, human geography, or urbanism to decision makers in the region. The results would be an opportunity to reduce poverty and to avoid future slums, which would positively affect poverty. In addition, improving urban mobility to access the labour market would redesign cities to support productivity, infrastructure development, quality of life, equity and social inclusion, the other major challenges in South America. Attending to the possible urban strategies, to reinforce centralities seems to be the most adequate.

\section{References}

ALKIRE S., FOSTER J. (2011), Counting and multidimensional poverty measurement, Journal of Public Economics 95 (7-8), 476-487.

ATKINSON W. (2008), Not all that was solid has melted into air (or liquid): A critique of Bauman on individualization and class in liquid modernity, The Sociological Review 56 (1), 1-17.

BAILEY N., LIVINGSTON M. (2008), Selective migration and neighbourhood deprivation: Evidence from 2001 census migration data for England and Scotland, Urban Studies 45 (4), 943961.

BASTIA T. (2015), Transnational migration and urban informality: Ethnicity in Buenos Aires' informal settlements, Urban Studies 52 (10), 1810-1825.

BAUER P. T. (1957), Economic Analysis and Policy in Underdeveloped Countries, Cambridge University Press, London.

BOCAREJO S. J. P., OVIEDO H. D. R. (2012), Transport accessibility and social inequities: a tool for identification of mobility needs and evaluation of transport investments, Journal of Transport Geography 24, 142-154. 
BORSDORF A., BÄHR J., JANOSCHKA M. (2002), Die Dynamik stadtstrukturellen Wandels in Lateinamerika im Modell der lateinamerikanischen Stadt (The dynamic of urban structural change in Latin America in the model of the Latin American city), Geographica Helvetica 57 (4), 300-310.

BOURDIEU P. (1990), The Logic of Practice, Stanford University Press, Stanford.

BOURGUIGNON F., CHAKRAVARTY S. R. (2019), The measurement of multidimensional poverty, In: Chakravarty S. (ed.), Poverty, Social Exclusion and Stochastic Dominance, Springer, Singapore, pp. 83-107.

BUSTAMENTE-PATIÑO B., HERRERO-OLARTE S. (2017), La clase dominante como determinante de la forma de Quito (The ruling class, determinant of Quito's shape), Bitácora Urbano Territorial 27 (3), 81-90.

CARDOSO F. H., FALETTO E. (1971), Dependencia y desarrollo en América Latina: ensayo de interpretación sociológica (Dependency and development in Latin America: a sociological interpretation essay), Siglo Veintiuno, Buenos Aires.

CARRIÓN F. (ed.) (1990), La Investigación Urbana en América Latina. Caminos Recorridos y por Recorrer: Estudios Nacionales (Urban Research in Latin America. Paths Travelled and to Go: National Studies), Ciudad, Quito.

CASTAÑEDA NORDMANN A. L., GÓMEZ LÓPEZ C. (2020), ¿Relocalización o bienestar social? Evaluación de las condiciones de accesibilidad en erradicaciones del Área Metropolitana de Tucumán (Relocation or social welfare? Evaluation of accessibility conditions in the eradications of Tucumán Metropolitan Area), Estudios Demográficos y Urbanos 35 (1), 185-214.

CASTELLS M. (2020), Space of flows, space of places: Materials for a theory of urbanism in the information age, in: LeGates R. T., Stout F. (eds.), The City Reader, Routledge, London, pp. 240-251.

COMMISSION OF THE EUROPEAN COMMUNITIES (1992), Towards a Europe of Solidarity: Intensifying the fight against social exclusion, fostering integration, Commission of the European Communities, Retrieved from: www.eur-lex.europa.eu.

COSTELLO M. A. (1987), Slums and squatter areas as entrepots for rural-urban migrants in a less developed society, Social Forces 66 (2), 427-445.

DE HAAN A. (1998), 'Social Exclusion': An Alternative Concept for the Study of Deprivation?, IDS Bulletin 29 (1), 10-19.

DE MATTOS C. A. (2002), Transformación de las ciudades latinoamericanas. ¿Impactos de la globalización? (Transformation of Latin American cities. Impacts of globalization?), EURE 28 (85), 5-10.

DELEECK H., VAN DEN BOSCH K. (1992), Poverty and Adequacy of Social Security in Europe: a Comparative Analysis, Journal of European Social Policy 2 (2), 107-120.

DENEULIN S., SÁNCHEZ-ANCOCHEA D. (2018), Urban inequality, youth and social policy in Latin America: introduction to special section, Oxford Development Studies 46 (1), 3-9.

DÍAZ-MÁRQUEZ Á. M. (2019), Revisión bibliográfica sobre la circulación de ideas urbanas en América Latina y el Caribe (Bibliographic review on the circulation of urban ideas in Latin America and the Caribbean), EURE 45 (134), 279-294.

DREWNOWSKI J., SCOTT W. (1966), The Level of Living Index, United Nations Research Institute for Social Development, Geneva.

DRĖZE J., SEN A., HUSSAIN A. (1995), The Political Economy of Hunger: Selected Essays, Oxford University Press, Oxford.

FIGUEROA A. (2001), Social exclusion and rural underdevelopment, in: Feinstein O. N., Picciotto R., Wolfensohn J. D. (eds.), Evaluation and poverty reduction, Routledge, New York, pp. 329-337.

FIGUEROA O. (2005), Transporte urbano y globalización. Políticas y efectos en América Latina (Urban transport and globalization. Policies and effects in Latin America), EURE 31 (94), 41-53. 
GACITÚA E., SOJO C., DAVIS S. H. (eds.) (2000), Exclusión Social y Reducción de la Pobreza en América Latina y Caribe (Social Exclusion and Poverty Reduction in Latin American and the Caribbean), FLACSO - The World Bank, San José.

GIUSTI J. (1973), Organización y participación popular en Chile: el mito del "hombre marginal" (Popular organization and participation in Chile: the myth of the "marginal man"), FLACSO, Santiago de Chile.

GOLDBERG M. M. (1941), A Qualification of the Marginal Man Theory, American Sociological Review 6 (1), 52-58.

GORE C., FIGUEIREDO J. B. (eds.) (1997), Social exclusion and anti-poverty policy: a debate, International Labour Organization, Geneva.

GREEN A. W. (1947), A Re-Examination of the Marginal Man Concept, Social Forces 26 (2), 167-171

GUZMAN L. A., OVIEDO D., BOCAREJO J. P. (2017a), City profile: the Bogotá metropolitan area that never was, Cities 60 (Part A), 202-215.

GUZMAN L. A., OVIEDO D., RIVERA C. (2017b), Assessing equity in transport accessibility to work and study: The Bogotá region, Journal of Transport Geography 58, 236-246.

GUZMAN JARAMILLO A., PHILIPS I., LUCAS K. (2019), 14 - Social impact assessment: The case of bus rapid transit in the City of Quito, Ecuador, in: Lucas K., Martens K., Di Ciommo F., Dupont-Kieffer A. (eds.), Measuring Transport Equity, Elsevier, Amsterdam, pp. 217-229.

HERRERO OLARTE S. (2019), Territorial Exclusion as a Limit to Urban Development: The Case of Quito, Ecuador, Theoretical and Empirical Researches in Urban Management 14 (4), 5369.

HERRERO-OLARTE S., DÍAZ-MÁRQUEZ A. (2020), Análisis de la relación entre accesibilidad y pobreza. Estudio de caso en Quito, Ecuador (Analysis of the relationship between accessibility and poverty. A case study in Quito, Ecuador), AUS [Arquitectura/Urbanismo/Sustentabilidad] 27, 50-58.

HIDALGO D., HUIZENGA C. (2013), Implementation of sustainable urban transport in Latin America, Research in Transportation Economics 40 (1), 66-77.

ITRANS (2004), Mobilidade e pobreza (Mobility and poverty), Instituto de Desenvolvimento e Informaçáo em Transporte, Retrieved from: www.mcadaval.com.br.

JOUFFE Y. (2011), Las clases socio-territoriales entre movilidad metropolitana y repliegue barrial. ¿Tienen los pobladores pobres una movilidad urbana de clase? (Socio-territorial classes between metropolitan mobility and neighborhood withdrawal. Do poor people have a class urban mobility?), Revista Transporte y Territorio 4, 84-117.

KABIR M. S., HOU X., AKTHER R., WANG J., WANG L. (2012), Impact of small entrepreneurship on sustainable livelihood assets of rural poor women in Bangladesh, International Journal of Economics and Finance 4 (3), 265-280.

KAZTMAN R. (2003), La dimensión espacial en las políticas de superación de la pobreza urbana (The spatial dimension in urban poverty alleviation policies), United Nations, Santiago de Chile.

KEELING D. J. (2008), Latin America's transportation conundrum, Journal of Latin American Geography 7 (2), 133-154.

LENOIR R. (1974), Les exclus: un Français sur dix (The excluded: one in ten French people), Seuil, París.

LUCAS K. (2012), Transport and social exclusion: where are we now?, Transport Policy 20, 105-113.

MACKINNON D., DRISCOLL DERICKSON K. (2013), From resilience to resourcefulness: A critique of resilience policy and activism, Progress in Human Geography 37 (2), 253-270.

MARTIN R., PIKE A., TYLER P., GARDINER B. (2016), Spatially rebalancing the UK economy: Towards a new policy model?, Regional Studies 50 (2), 342-357. 
Identifying Patterns of Labour Exclusion by Residential Causes in South America: The Case of Quito

MASSEY D. S., WHITE M. J., PHUA V.-C. (1996), The dimensions of segregation revisited, Sociological Methods \& Research 25 (2), 172-206.

MAXWELL S. (1998), Comparisons, Convergence and Connections: Development Studies in North and South, IDS Bulletin 29 (1), 20-31.

MIRALLES-GUASCH C. (2002), Ciudad y Transporte: el binomio imperfect (City and Transport: the imperfect binomial), Ariel, Barcelona.

MIRALLES I GUASCH C., TULLA I PUJOL A. F., CEBOLLADA A., REQUENA R. (2000), Mobilitat sostenible: innovacions conceptuals $i$ estat de la qüestió (Sustainable mobility: conceptual innovations and state of the art), Universitat Autònoma de Barcelona, Retrieved from: portalrecerca.uab.cat.

MURMIS M. (1969), Tipos de marginalidad y posición en el proceso productive (Types of marginality and position in the production process), Revista Latinoamericana de Sociología 2, 413421.

MUWONGE J. W. (1980), Urban policy and patterns of low-income settlement in Nairobi, Kenya, Population and Development Review 6 (4), 595-613.

OVIEDO D., SCHOLL L., INNAO M., PEDRAZA L. (2019), Do bus rapid transit systems improve accessibility to job opportunities for the poor? The case of Lima, Peru, Sustainability 11 (10), 2795.

PAES DE BARROS R., FERREIRA F. H. G., MOLINAS VEGA J. R., SAAVEDRA CHANDUVI J. (2008), Midiendo la desigualdad de oportunidades en América Latina y el Caribe (Measuring the inequality of opportunities in Latin America and the Caribbean), The World Bank, Washington, D.C.

PALACIO LUDEÑA M. G., DÍAZ PABÓN F. A. (2020), Urban inequality and protests in Ecuador and Chile, SALDRU, Cape Town.

PARK R. E. (1928), Human migrations and the marginal man, American Journal of Sociology 33, 881-893.

PERLMAN J. (1977), O Mito da Marginalidade: favelas e política no Rio de Janeiro (The Myth of Marginality: favelas and politics in Rio de Janeiro), Paz e Terra, Rio de Janeiro.

PÉREZ VALBUENA G. J., SALAZAR MEJÍA I. (2008), La pobreza en Cartagena: un análisis por barrios (Poverty in Cartagena: an analysis by barrios), Revista del Banco de la Republica 82 (967), 16-55.

PORTES A. (1976), The Economy and Ecology of Urban Poverty, in: Portes A., Walton J. (eds.), Urban Latin America: The Political Condition from Above and Below, University of Texas Press, Austin, pp. 7-69.

PREECE J. (2018), Immobility and insecure labour markets: An active response to precarious employment, Urban Studies 55 (8), 1783-1799.

PRÉVÔT SCHAPIRA M.-F. (2000), Segregación, fragmentación, secesión. Hacia una nueva geografía social en la aglomeración de Buenos Aires (Segregation, fragmentation, secession. There is a new social geography in the agglomeration of Buenos Aires), Economía, Sociedad y Territorio 2 (7), 405-431.

RODRÍGUEZ VIGNOLI J. (2001), Segregación residencial socioeconómica: ¿qué es?, ¿cómo se mide?, ¿qué está pasando?, ¿importa? (Socioeconomic residential segregation: what is it? how is measure it? does it matter? what is happening?), United Nations. CEPAL, Santiago de Chile.

RODRÍGUEZ VIGNOLI J. (2008), Movilidad cotidiana, desigualdad social y segregación residencial en cuatro metrópolis de América Latina (Daily mobility, social inequality and residential segregation in four Latin American metropolises), EURE 34 (103), 49-71.

ROOM G. (ed.) (1992), Observatory on national policies to combat social exclusion, Commission of the European Communities, Retrieved from: researchportal.bath.ac.uk. 
SABATINI F., ARENAS F. (2000), Entre el Estado y el mercado: resonancias geográficas y sustentabilidad social en Santiago de Chile (Between the State and the market: geographic resonances and social sustainability in Santiago de Chile), EURE 26 (79), 95-113.

SABATINI F., SARELLA ROBLES M., VÁSQUEZ H. (2009), Gentrificación sin expulsión, o la ciudad latinoamericana en una encrucijada histórica (Gentrification without expulsion or the historical crossroads of the Latinamerican city), Revista_180 24, 18-25.

SANZ A. (2005), El viatge de les paraules (The journey of words), SAM 3, 7-14.

SECRETARY OF STATE FOR SOCIAL SECURITY (1999), Opportunity for All: Tackling Poverty and Social Exclusion, The Stationery Office, London.

SEERS D. (1969), The meaning of development, Institute of Development Studies, Retrieved from: www.ids.ac.uk.

SEN A. (1997), Resources, Values and Development, Harvard University Press, Cambridge.

SEN A., WILLIAMS B. (eds.) (1982), Utilitarianism and beyond, Cambridge University

Press, Cambridge.

SEPÚLVEDA MORALES R. (2019), Evolución de la segregación residencial: grupos ocupacionales y politicas de vivienda popular en el gran Santiago, 1960-2005 (Evolution of residential segregation: occupational groups and popular housing policies in Greater Santiago, 1960-2005), Universidad de Chile, Santiago de Chile.

SHOVE E. (2002), Rushing around: coordination, mobility and inequality, Lancaster University, Retrieved from: www.lancaster.ac.uk.

SILVER H. (1994), Exclusión social y solidaridad: Tres paradigmas (Social exclusion and solidarity: Three paradigms), Revista Internacional del Trabajo 113 (5-6): 607-662.

SINGER P. (1977), Desenvolvimento Econômico e Evolução Urbana, Análise da Evolução Econômica de São Paulo, Blumenau, Porto Alegre, Belo Horizonte e Recife (Economic Development and Urban Evolution, Analysis of the Economic Evolution of São Paulo, Blumenau, Porto Alegre, Belo Horizonte and Recife), Companhia Editora Nacional, São Paulo.

SLACK J., MARTÍNEZ D. E., LEE A. E., WHITEFORD S. (2016), The Geography of Border Militarization: Violence, Death and Health in Mexico and the United States, Journal of Latin American Geography 15 (1), 7-32.

SMITH W. C. (1934), The Hybrid in Hawaii as a Marginal Man, American Journal of Sociology 39 (4), 459-468.

TACHNER S. P., BÓGUS L. M. M. (2001), São Paulo, uma metrópole Desigual (São Paulo, an unequal metropolis), EURE 27 (80), 87-120.

TITHERIDGE H., CHRISTIE N., MACKETT R., OVIEDO HERNÁNDEZ D., YE R. (2014), Transport and poverty: A Review of the Evidence, University College London, Retrieved from: www.ucl.ac.uk.

TOWNSEND P. (1979), Poverty in the United Kingdom: A Survey of Household Resources and Standards of Living, Penguin Books, Harmondsworth.

UNDA M. (1990), La Investigación Urbana en América Latina: Caminos Recorridos y por Recorrer. Viejos y nuevos temas (Urban Research in Latin America: Roads and Trails. Old and New Topics), CIUDAD, Quito.

UNITED NATIONS (1963), Social development of Latin America in the post-war period, United Nations, Retrieved from: repositorio.cepal.org.

UNITED NATIONS (2014), World Urbanization Prospects: The 2014 Revision, Department of Economic and Social Affairs: Population Dynamics, Retrieved from: population.un.org.

UN-HABITAT (2003), The challenge of slums: global report on human settlements 2003, Earthscan, London.

VEKEMANS R., SILVA I. (1969), La Marginalidad en América Latina: un ensayo de conceptualización (Marginality in Latin America: an essay on conceptualization), DESAL, Santiago de Chile. 
Identifying Patterns of Labour Exclusion by Residential Causes in South America: The Case of Quito

VENTER C. (2016), Assessing the potential of bus rapid transit-led network restructuring for enhancing affordable access to employment - The case of Johannesburg's Corridors of Freedom, Research in Transportation Economics 59, 441-449.

WILSON W. J. (2012), The Truly Disadvantaged: The Inner City, the Underclass, and Public Policy, The University of Chicago Press, Chicago.

ZALAKEVICIUTE R., RYBARCZYK Y., LÓPEZ-VILLADA J., DIAZ SUAREZ M. V. (2018), Quantifying decade-long effects of fuel and traffic regulations on urban ambient PM2.5 pollution in a mid-size South American city, Atmospheric Pollution Research 9 (1), 66-75.

ZÁRATE C. N. (2018), Qué esperar tras el fin de los subsidios anunciados (What to expect after the end of the announced subsidies), GK, Retrieved from: www.gk.city.

ZOHIR S. (2006), Participation of non-government organizations in the delivery of social services, in: Ahmed S., Mahmud W. (eds.), Growth and poverty: the development experience of Bangladesh, University Press Limited, Dhaka, pp. 285-304.

Initial submission: 27.02 .2020

Revised submission: 30.11 .2020

Final acceptance: 22.12 .2020

Correspondence: Centro de Investigaciones Económicas y Empresariales (CIEE), Facultad de Ciencias Económicas y Administrativas, Universidad de Las Américas, Av. de los Granados E12-41 y Colimes esq., Quito EC170125, Ecuador.

Email: olartesusana@hotmail.com 
